\title{
Development of Learning Media for Educational Games Based on Adobe Flash in Biology
}

\author{
S Syafruddin \\ Biologi Education \\ Universitas Samawa \\ Sumbawa, Indonesia \\ syafruddinfkip@gmail.com \\ Wiwi Noviati \\ Biologi Education \\ Universitas Samawa \\ Sumbawa, Indonesia \\ wiwinoviati15@gmail.com
}

\author{
Indah Dwi Lestari* \\ Biologi Education \\ Universitas Samawa \\ Sumbawa, Indonesia \\ indahlestari656@gmail.com \\ Eryuni Ramdhayani \\ Biologi Education \\ Universitas Samawa \\ Sumbawa, Indonesia
}

\begin{abstract}
This research aims to develop learning media for educational games based on Adobe Flash in biology. This study is also aimed to determine the feasibility of an adobe flash-based educational game based on the assessment from material experts, media experts, practitioners and students. This research is a research development $(R \& D)$ adapted and modified from the development model of Borg \& Gall. The stages include: the preliminary study stage, the planning stage, the initial product development stage, the initial trial stage, the first product revision, the limited field trial stage and the second product revision. In the initial product development stage, material validation was carried out by one material expert (lecturer), media validation by one media expert (lecturer) and one expert practitioner (teacher). This educational game was tried out on students in two stages, namely the initial trial stage (10 students) and the limited field trial stage (20 students). The data collection technique in this study was a questionnaire. The data obtained from the questionnaire were then analyzed descriptively, qualitatively and quantitatively. The feasibility level of learning media for educational games based on Adobe Flash for biology subjects based on the following assessments: 1) Material Experts obtained an average score of 4.05 which is included in the Eligible category, 2) Media Experts obtained an average score of 4.114 which is in the Eligible category, 3 ) Practical experts obtained an average score of 4.05 which is included in the Eligible category, 4) The Initial Trial obtained a score of $\mathbf{4 . 5 2}$ which is in the Very Appropriate category, 5) Limited Field Trials obtained a score of 4.72 in the Very Appropriate category. Thus, this educational game development is suitable to use as a media for learning biology
\end{abstract}

Keywords-Biology Learning Media, Educational Games, Adobe Flash, Biology

\section{INTRODUCTION}

The development of science and technology runs so rapidly. This situation demands that life in this era cannot be separated from the latest technology. The technologies developed must have benefits for human life, namely to facilitate and assist human daily activities in various fields. People must be able to adapt and use technology so that existing technology can be useful. Education, for example, brings a positive impact to the development of technology. In the past, when technology was not as sophisticated as it is today, the learning process was very dependent on the teacher as a sole learning resource. Computer technology has been experiencing a quite rapid development in which it, in turn, has also caused a change in life styles. The tangible example is in the use of computer technology [1]. Now, the learning process is no longer relied upon the presence of teachers. In fact, current technology allows students to study anywhere, anytime, and with anyone[2]. This technological development also encourages the world of education to always strive to make updates and take advantage of existing technology in the learning process. For schools, the use of this technology is realized by providing information technology facilities to support the learning process[3]. Information technology has a huge impact on education in Indonesia in particular. As such, teachers can get the latest and most up-to-date references in terms of material and in learning media.

One school that already has information technology-based facilities is Madrasah Aliyah Negeri 1 Sumbawa Besar. Each classroom at MAN 1 Sumbawa Besar is equipped with a Liquid Crystal Display (LCD) projector. In addition, the school also has a computer laboratory. The use of this technology, provided by the school, must also be optimized by teachers as educational subjects who play an important role in the direction of the learning process. Teachers are required to be able to use technology-based facilities that have been provided by schools to support teaching and learning activities. In addition to being able to use the available tools, teachers are also required to develop learning media. Based on the results of observations 
conducted at MAN 1 Sumbawa Besar towards class $\mathrm{X}$ students, it shows that teachers have yet to utilize the learning media. They only employ worksheets and power point slides in the classroom. One way to create effective and fun learning is by implementing interactive learning media[4]. Interactive learning media are all tools or materials to achieve learning objectives that can engage students in the learning process, one of which is by using LCD.

Games as computer-based interactive learning media have good potential. Currently, the use of games as learning media has not been developed much, especially in biology learning media adobe flash. Meanwhile, it is a difficult lesson because of its rote nature with many use Latin words so that with the help of developed media it can increase learning motivation because it creates pleasant learning conditions. With increased learning motivation, it can encourage student achievement [5]. If it is developed properly, it can be used as a very interesting alternative learning media. This is because games are in great demand because they are fun and entertaining. This can be used as a basis for teachers to try to package learning with games [2].

The educational game that the author has developed is a form of audio-visual learning media, namely media that can be seen and heard, because besides having an image element it also has a sound element so that this media is considered better and more interesting. The educational game that will be developed by the author is educational which is included in the type of game and educational. Quiz game is a game where players will act as participants in a quiz.

\section{METHODS}

This research employs Borg \& Gall's model development procedures (1983). Borg \& Gall explained that $R \& D$ research is a process used to develop and validate educational products that can be learning, learning media, and systems management. This research is focused on media product development learning in the form of games which has been integrated in Biology lessons at MAN I Sumbawa Besar. The subject of this study is a validator material expert, instructional media expert, expert practitioner, 10 students on the trial starters and 20 students on the test try a limited field. The object of this research is game eligibility. The data collection technique in this study used a questionnaire. The data obtained from the questionnaire were then analyzed descriptively, qualitatively and quantitatively

\section{RESUlT AND DISCUSSION}

Educational games developed are included in the types of games and educational. Quiz games are games where players will act as participants in a quiz using the Borg \& Gall (1983) development model which includes material development, media and evaluation. The product results can be seen in the following image:

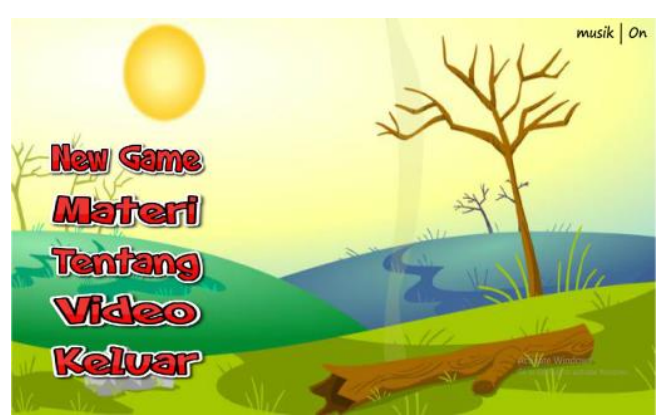

Fig. 1. Main Course

The main menu is the initial display that is used as a map to open all the menus in the game. This menu is made attractive and, of course, very clear, so that students are interested in using it.

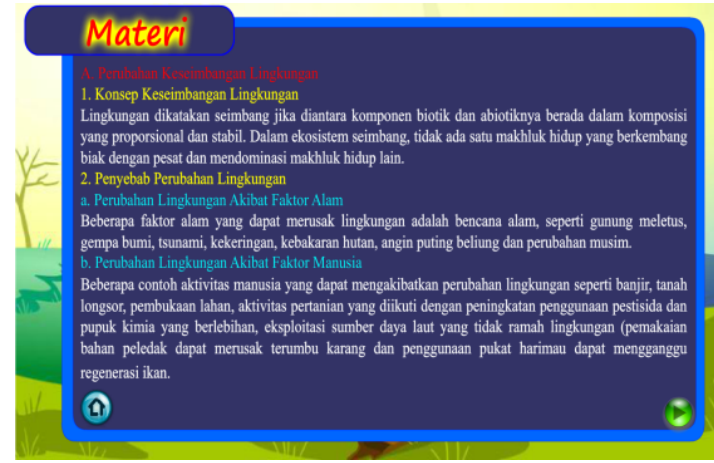

Fig. 2. Menu Material

The material menu is presented aims to help users to make it easier to complete existing games. The material is presented in text form

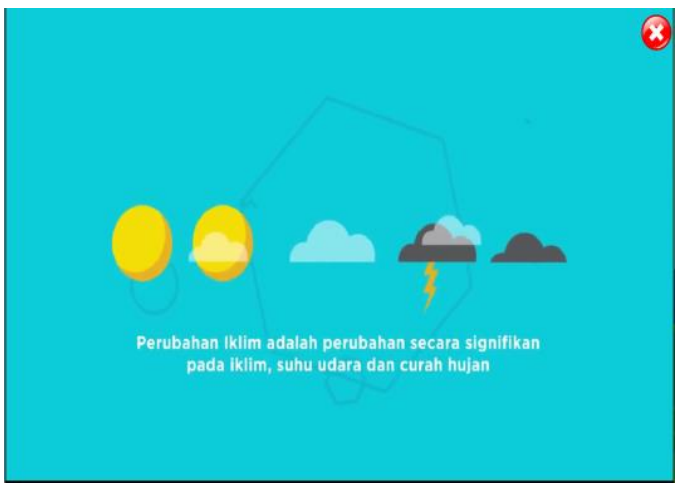

Fig. 3. Menu Video

The video menu is presented to assist users in understanding the previously presented material. So that the explanation obtained is broader 


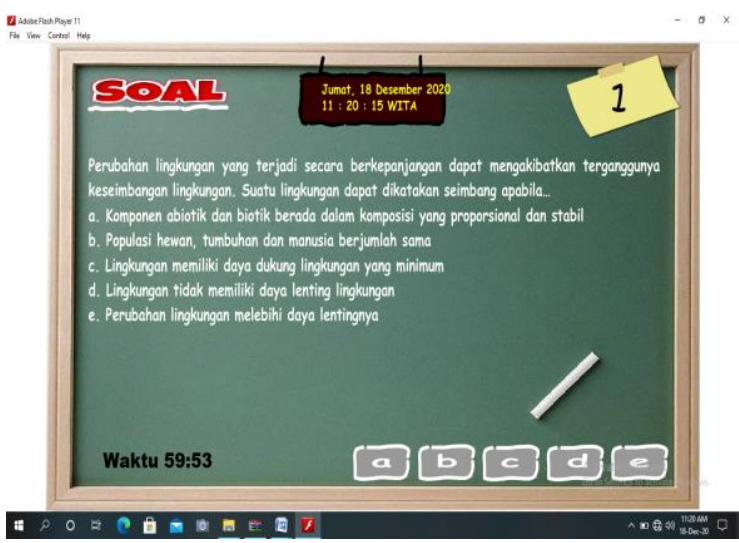

Fig. 4. Menu Test Games

The question menu is the menu used by students in the game that has been adjusted to the material that has been studied and what is already in this educational game.

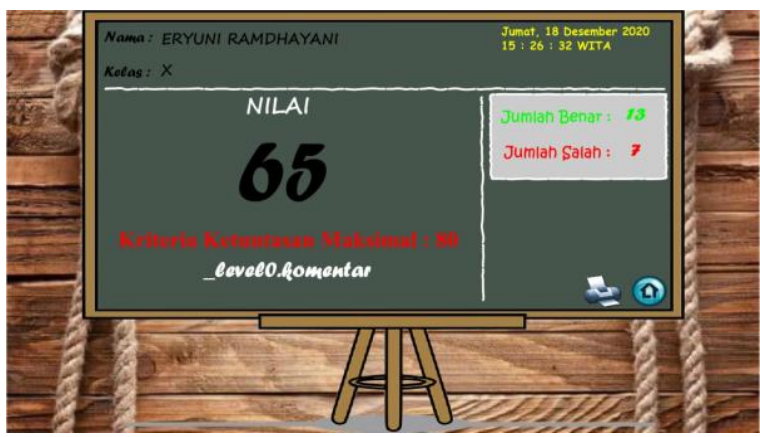

Fig. 5. Menu Score

The score menu is used to find out the score that can be obtained from the results of the game. The values displayed on this menu are in the form of numbers, making it easier for users to see the results being done

\section{A. Eligibility for Interactive Games}

- Eligibility by Material Experts

The material feasibility assessment is carried out by one material expert. The material expert is a lecturer in Biology Education, Faculty of Teacher Training and Education, Samawa University. The assessment score by material experts can be seen in Table I.

\section{TABLE I. MATERIAL EXPERT} VALIDATION RESULTS

\begin{tabular}{cll}
\hline Eligibility Aspects & Total Score & Average \\
\hline 1. Material & 38 & 3.8 \\
2. Language & 13 & 4.3 \\
3. Test & 22 & 4.4 \\
Total & 73 & \\
Average & 4.05 & \\
\hline Category & & Worthy \\
\hline
\end{tabular}

- Material Expert Validation Results
The media feasibility assessment was carried out by one media expert. The media expert is a lecturer in Physics Education at the Teacher Training and Education Faculty, Samawa University. The assessment score by material experts can be seen in table II

\begin{tabular}{lcc}
\multicolumn{1}{c}{ TABLE II. } & \multicolumn{2}{c}{$\begin{array}{c}\text { MEDIA EXPERT VALIDATION } \\
\text { RESUlTS }\end{array}$} \\
& & \\
\hline Eligibility Aspects & Total score & Average \\
\hline 1. Software engineering & 37 & 4.41 \\
2. Visual communication & 50 & 4.17 \\
Totale & 87 & \\
Average & 4.14 & \\
\hline Kategori & \multicolumn{3}{c}{ Worthy } \\
\hline
\end{tabular}

- $\quad$ Eligibility by Expert Practitioners

A practitioner's eligibility assessment is carried out by one practitioner expert. The expert practitioner is a teacher at MAN 1 Sumabawa Besar. The assessment score by material experts can be seen in table III.

\section{TABLE III. PRACTITIONERS EXPERT} VALIDATION RESULTS

\begin{tabular}{ccc}
\hline Eligibility Aspects & Total score & Average \\
\hline 1. Software engineering & 18 & 4.50 \\
2. Learning design & 27 & 3.85 \\
3. Visual communication & 32 & 4.00 \\
Total & 77 & \\
Average & 4.05 & \\
\hline Category & \multicolumn{2}{c}{ Worthy } \\
\hline
\end{tabular}

\section{B. Initial Field Trials}

The preliminary trial was carried out after the author made revisions to the games developed based on the validation results of material experts, media experts and practitioners. The initial trial was carried out on 10 students of MAN 1 Sumbawa class XI IA 2. This was done to determine the assessment of interactive games. The test results can be seen in table IV.

TABLE IV. RECAPITULATION OF PRELIMINARY TRIAL RESULTS

\begin{tabular}{ccc}
\multicolumn{1}{c}{} & & \\
\hline Eligibility Aspects & Total score & Average \\
\hline 1. Software engineering & 196 & 4.90 \\
2. Learning design & 300 & 4.29 \\
3. Visual communication & 362 & 4.53 \\
Total & 862 & \\
Average & 4.52 & \\
\hline Category & Very worthy \\
\hline
\end{tabular}

\section{Limited Field Trials}

Limited field trials were carried out after the author finishing evaluation phase on the preliminary trial. This trial was conducted on 20 students of MAN 1 Sumbawa class XI IA 2. The test results can be seen in table V. 
TABLE V $\quad$ RECAPITULATION OF LIMITED FIELD TRIAL RESULTS

\begin{tabular}{cll}
\hline Eligibility Aspects & Total score & Average \\
\hline 1. Software engineering & 384 & 4.8 \\
2. Learning design & 654 & 4.67 \\
3. Visual communication & 755 & 4.72 \\
Total & 1.793 & \\
Average & 4.72 & \\
\hline Category & \multicolumn{3}{c}{ Very worthy } \\
\hline
\end{tabular}

In this discussion, a revised review of the product development results is presented, including the suitability of the resulting product in accordance with the research objectives, the advantages and disadvantages of the developed products, as well as the relevant research results. The purpose of this research on the development of learning media for learning games based on adobe flash is to determine the feasibility of an adobe flash based educational game based on the assessment of material experts, media experts, practitioners and students.

Researchers' material determined based on the results of a preliminary study by analyzing the results of the 2015/2016 and 2016/2017 National Examinations, namely environmental material. As well as compiling a media assessment instrument in the form of a questionnaire for material experts, media experts, learning practitioners (teachers), and students. A questionnaire or questionnaire is used to assess the feasibility of educational game media. Then, the researcher compiled the material framework and questions based on the basic competencies and learning objectives to be achieved, then the researcher developed it into a material framework to be delivered in the game. Furthermore, the material framework is used as a reference for compiling 20 questions. After compiling the material and questions, the researchers then compiled the flowchart and story board. Flowchart is a game flowchart that serves as a reference for writers in making games. Meanwhile, the Story board is a description for each picture. The story board is created to describe all the components in each display. To determine the feasibility of the media, the next step is validation by experts. The validators, namely, one material expert lecturer, one media expert lecturer, and one biology learning practitioner expert. Researchers made revisions to the learning media for educational games based on Adobe Flash in order to obtain appropriate media to be tested on the test subjects. Educational game learning media were tested on the subject of initial trials and limited field trials. For the preliminary trial, the number of research subjects was 10 students and the field trial was limited with 20 students. Field test which aims to determine the feasibility of the product being developed. The revision stage of the development of educational game learning media is to improve the results of all suggestions / comments and recapitulate the feasibility assessment by material experts, media experts, learning practitioners and students. Learning outcomes are in the context of video games and are viewed from two theoretical frameworks: Kirkpatrick's levels of evaluation and the CRESST model of learning. These are used to analyse the outcomes claimed in journal articles that report empirical work, indicating the usefulness of the frameworks, and the necessity to consider the role of affective learning. The article ends with some comments on the relationship of instructional design to effective games and learning outcomes [6].

The development of learning media for educational games based on Adobe Flash starts from the preliminary study stage, which is to collect various information used as a reference in creating a development product. Based on field studies that have been carried out by researchers as a means of observation, it shows that there is still a lack interests in teachers in using learning media as it is only traditionally based on the use of student worksheets and power point media and the learning media of adobe flash based educational games have never been applied. These problems certainly affect students' interest and motivation. So this adobe flash based game can be an alternative media for teachers to teach so that students can be more motivated. According to Leonardo et al. quoted in [7], the impact of educative games is to train children's concentration, teach more quickly and effectively, increase understanding and memory, make the learning process fun. Meanwhile, according to [8], the implementation of games in the classroom have had a very positive impact on student learning outcomes. In line with the opinion of Dwiyono (2017) [9] that through educational games the learning atmosphere becomes more interesting. Thus, the development of educational games as learning media is expected to provide a pleasant atmosphere in the learning process. Apart from direct action, it can also be applied in formal educational activities, of course with various learning media developed by educators in the best way to get optimal results [10]. In line with the opinion of Susanto [11], students can learn independently using interactive multimedia student educational games and help teachers explain material in a fun way.

The advantages of developing this product are: (1) learning with educational game media can be used by science teachers as an alternative teaching media that can increase students' interest in learning, (2) environmental pollution material that is abstract enough to understand, with adobe-based educational games. This flash will be more concrete because there are questions, material that will be easy for students to understand, (3) educational games are easy to use because they can be used with computers, (4) multimedia educational games based on adobe flash are interesting and interactive by providing challenging games, materials, videos, which the user has to complete.

Technology and learning media in the classroom using multimedia are needed nowadays, especially when developed with various innovative learning models [12]. According to Nurhabibie , computer 
games are animations in the form of videos that can be moved and games that are made as learning media are expected to provide a challenging atmosphere in the classroom so that the learning process will not be noticed [13]. Based on the result of research by Allsop teacher in England and Italy are interested in teaching with digital games as an effective educational tool [14]. The weaknesses of educational game-based science media products are that the material simulation is still incomplete and the variation of questions still needs to be further developed. Educational games are games that are packaged to stimulate thinking and including one way to train to increase the concentration of users [15].

\section{CONCLUSION}

Based on the results of research and discussion, the following conclusions can be drawn: Educational game development goes through 7 main stages of development, namely the preliminary study stage, the planning stage, the initial product development stage, the initial trial stage, the first product revision, limited field testing and the second product revision. The feasibility level of educational games is reviewed based on the assessment of material experts, media experts, practitioners and students. The feasibility assessment by the expert declared the product in the feasible category while the assessment by students in the preliminary and limited trials was included in the very feasible category.

\section{REFERENCES}

\& N. Martono, K. T., "Implementation of android based mobile Learning application as a flexible learning Media," Int. J. Comput. Sci. Issues (IJCSI, vol. 11 , no. 3, p. 168,2014

[2] Z. A.Wibowo, "In Class XI Accounting at SMK YPE Saunggalih Kutoarjo. Development of Educational Game Tax Administration Millionerquiz Based on Adobe Flash as a Learning Medium for Tax Administration.Universitas Negeri Yogyakarta," UNY.

[3] W. Noviati, "Difficulties of Online Learning of Biology Education Students in the Middle of a Pandemic Covid
19," J. Pendidik. MIPA, vol. 10, no. 1, pp. 7-11, 2020.

[4] and F. V. P. A.Qosyim, "Penerapan Media Pembelajaran Interaktif Menggunakan Flash Untuk Materi Sistem Gerak Pada Manusia Kelas VIII," J. Penelit. Pendidik. IPA, vol. 2, no. 2, pp. 38-44, 2018

[5] Syafruddin, "Analysis of Learning Motivation of Prospective Biology Teachers at Samawa University," . Indones. J. STEM Educ., vol. 2, no. 1, pp. 11-18, 2020

[6] E. L. O'Neil, H. F., Wainess, R., \& Baker, "Classification of learning outcomes: Evidence from the computer games literature," Cirriculum J., vol. 16, no. 4, pp. 455-474, 2005.

[7] Febriani, "Educative Game Development Based on Android Applications To facilitate reading skills of children aged 5-6 years," J. PAUD Agapedia, vol. 2, no. 2, pp. 187-196, 2018.

[8] I. P. I. K. N.W. S. Mahayanti, G.A.P. Suprianti, "Language Learning Games Development Based on curriculum 2013," . J. Educ. Technol., vol. 1, no. 1, pp. 61-70.

[9] Dwiyono, "Education game development as interactive learning media of describes hand tools and power tools subject," E-Jurnal Progr. Stud. Pendidik. Tek. mekatronika, vol. 1, no. 4, pp. 343-351.

[10] and E. R. D. Wardaniah, I.D. Lestari, "Ekoliterasi Siswa melalui Kegiatan Pengelolaan Sampah Berbasis Groupinvestigation di SMAN 1 Moyo Utara Tahun Pelajaran 2017/2018," J. Educ. Lang. Teach. Sci., vol. 1, no. 2, pp. 32-37, 2019.

[11] A. I. Susanto, N.R. Dewi, "Pengembangan Multimedia Interaktif Dengan Education Game Pada Pembelajaran IPA Terpadu Tema Cahaya Untuk Siswa SMP/MTS," Unnes Sci. Educ. J., vol. 2, no. 1, pp. 230-238, 2013.

[12] M.C. Arcega, "Instructional technology and media for learning," Rev. Mex. Investig. Educ., vol. 15, no. 44, pp. 191-196, 2010

[13] F. Y. Nurhabibie, "Education Game Development as self learning media in basic hydraulic subject and hydraulic component subject student vocational school 3 wonosari," . E-Jurnal Progr. Stud. Pendidik. Tek. mekatronika, vol. 1, no. 4, pp. 87-95, 2017.

[14] \& J. J. Y. Allsop., "Teachers Experience and Reflection on Game Base Learing in the Primary Classroom: Views from England and Italy," . Int. J. Game-Based Learn., vol. 5, no. 1, pp. 1-17, 2015.

[15] D. ] Rahman, R. A., \& Tresnawati, "Pengembangan game edukasi pengenalan nama hewan dan habitatnya dalam 3 bahasa sebagai media pembelajaran berbasis multimedia," J. Algoritm., vol. 13, no. 1, pp. 184-190, 2016. 